\title{
Evaluation of the National Food Security Act (NFSA) Programme in Odisha
}

\author{
Kedarnath Mallick* and B.P. Mohapatra \\ Department of Extension Education, College of Agriculture, Odisha University of Agriculture \\ \& Technology, Bhubaneswar, Odisha, India \\ *Corresponding author
}

\begin{abstract}
A B S T R A C T
Public Distribution System (PDS) is a poverty alleviation programme and contributes towards the social welfare of the people. Essential commodities like rice, wheat, sugar, kerosene and the like are supplied to the people under the PDS at reasonable prices. The result revealed that, almost all of the $(95 \%)$ beneficiaries had opined that, they were getting the ration in time except in some occasions. A total of $96.67 \%$ of the rural and $93.33 \%$ of the urban respondents had this opinion on the timely availability of the ration by the FPS. It is required that as per the NFSA norms the food grain provided to the beneficiaries should be at par with the sample put in their respective FPS. The data revealed that though $92.67 \%$ of the beneficiaries of the rural areas revealed that the quality was the same but $61.33 \%$ of the urban beneficiaries felt the same. Almost all the beneficiaries of the rural $(100 \%)$ as well as the urban $(98.67 \%)$ sample area were getting full quota of the food grains as per their own opinion. It was noticed that, the rural respondents were almost satisfied about the issue and majority (92.67\%) of the rural beneficiaries had no complain about the opening of the ration shops. However, $74.67 \%$ of the urban beneficiaries had satisfied about the issue and only $20 \%$ of them had complained that, the timing of the opening was not fixed and they missed the ration due to this reason sometimes.
\end{abstract}

\section{Keywords}

Evaluation, National food security act, PDS

Article Info

Accepted:

17 June 2020

Available Online:

10 July 2020

\section{Introduction}

Public Distribution System (PDS) is a poverty alleviation programme and contributes towards the social welfare of the people. Essential commodities like rice, wheat, sugar, kerosene and the like are supplied to the people under the PDS at reasonable prices. PDS is a boon to the people living below the poverty line. PDS is the primary social welfare and antipoverty programme of the
Government of India. Revamped Public Distribution System (RPDS) has been initiated by the Government of India from the year 1992 in order to serve and provide essential commodities to the people living in remote, backward and hilly areas. Government introduced Targeted Public Distribution System (TPDS) in the year 1997. Central Government and State Governments have been actively involved in steering the operations for the success of the PDS. The 
Government of India has enacted the National Food Security Act (NFSA) on September 12, 2013.

The National Food Security Act, 2013 (also Right to Food Act) is an Act of the Parliament of India which aims to provide subsidized food grains to approximately two thirds of India's 1.2 billion people. It was signed into law on 12 September 2013, retroactive to 5 July 2013. The National Food Security Act, 2013 (NFSA 2013) converts into legal entitlements for existing food security programmes of the Government of India. It includes the Midday Meal Scheme, Integrated Child Development Services scheme and the Public Distribution System. Further, the NFSA 2013 recognizes maternity entitlements. The Midday Meal Scheme and the Integrated Child Development Services Scheme are universal in nature whereas the PDS will reach about two-thirds of the population $(75 \%$ in rural areas and $50 \%$ in urban areas).

Both the central and state governments are equally responsible for the proper functioning of the Public Distribution System. The central government is responsible for the procurement, storage, transportation and allocation of the food grains and the state governments are responsible for distributing the food grains to the consumers through Fair price shops (FPS) which are also known as ration shops. The state government is also responsible for operational responsibility including identification of families below poverty line (BPL), issue of ration cards, supervision and monitoring the functioning of the fair price shops.

\section{Materials and Methods}

For the study, survey as well as Ex-Post Facto research was considered most appropriate to gather data. Multiphase sampling technique was adopted to select the districts, blocks, panchayats, villages and respondents. As the research study was subjective and analytical in nature, the survey research had been conducted through structured interview schedule and data collection from the sample beneficiaries of Cuttack district.

The data was obtained from 150 beneficiaries from rural and 150 beneficiaries from urban sample areas. Random sampling procedure was followed for selection of blocks, villages and sample respondents of the programme. The data was obtained from a total of 300 beneficiaries from 10 randomly selected villages of the sample area (5 from rural and 5 villages from urban blocks).

\section{Results and Discussion}

It is highly required that the commodities supplied by the government order the PDS of NFSA should reach the targeted beneficiaries in due time, in proper sanitation, quality of the food items and in true quantity. It is often said and discussed that the required benefits are not reaching the intended people properly and there are lots of by-pass mechanism do exist in the system. This evaluation study aimed at analyzing those crucial areas of timely availability, quality and quantity of the food grains for the sample beneficiaries.

\section{Opinion about the timely availability of PDS materials}

The success of any developmental programme depends on the timely availability of the intended benefits to the target audience. The beneficiaries under the PDS should get the food materials in due time and in proper quantity throughout the year. It is noticed that in many studies the authors revealed that the beneficiaries under the NFSA are not getting the ration in proper time and quantity. Hence the response of the sample respondents is obtained for analysis. 
The result revealed that, almost all of the (95\%) beneficiaries had opined that, they were getting the ration in time except in some occasions. A total of $96.67 \%$ of the rural and $93.33 \%$ of the urban respondents had this opinion on the timely availability of the ration by the FPS. It was indeed a highly satisfactory note that, the beneficiaries were getting their legitimate commodities in proper time. On probing some of the urban beneficiaries opined that, due to transportation problem they were getting the ration a bit late in a few occasions. A non significant $\mathrm{CR}$ value denoted that, there was no difference of opinion between the rural and the urban sample beneficiaries as far as the timeliness of obtaining of ration were concerned.

\section{Regularity of ration throughout the year}

The beneficiaries under the NFSA are getting the ration under the PDS throughout the year in each month. It may so happen that, some of them are getting the irregular ration delivery and getting two months / three months ration at a time after the stipulated month due to system constraints.

While in the focused group discussion with the sample respondents in both rural as well as the urban areas, it was noticed that, due to strict governance in the state, and due to the effect of vigilance machinery, most of them were getting the ration regularly in each month with negligible deviations.

The result revealed that, a large majority of the $(93.33 \%)$ beneficiaries had opined that, they were getting the ration regularly throughout the year except a very few occasions. A total of $94 \%$ of the rural and $92.67 \%$ of the urban respondents had this opinion on the regular availability of the ration by the FPS. It was indeed a highly satisfactory note that, the beneficiaries were getting their legitimate commodities in proper time and regularly throughout the year.
On probing some of the urban beneficiaries opined that, due to closing of their respective FPS for some reasons and due to the transportation problem they were getting the ration a bit late in a few months. A non significant $\mathrm{CR}$ value denoted that, there was no difference of opinion between the rural and the urban sample beneficiaries as far as the regularity of obtaining of ration were concerned.

\section{Quality of food grains}

Quality of any food material is utmost important for any beneficiary. It is always checked with many parameters before final delivery to the targeted people. But the beneficiaries are the best evaluators of the materials supplied to them.

It is required that as per the NFSA norms the food grain provided to the beneficiaries should be at par with the sample put in their respective FPS. The data revealed that though $92.67 \%$ of the beneficiaries of the rural areas revealed that the quality was the same but $61.33 \%$ of the urban beneficiaries felt the same. It was a matter of some concern that $36.67 \%$ of the urban beneficiaries under NFSA felt that the quality of the food grains was not same as the sample given. It was observed that though the rural beneficiaries were mostly getting good quality of commodities a few of urban beneficiaries were not happy about this parameter.

However, the pooled data revealed that as high as $77 \%$ of the beneficiaries under NFSA were satisfied about the quality of the commodities. A strong and highly significant critical ration value observed with reference to the urban and rural sample opinion. There was much significant difference on the quality of the food grains as per the opinion of the beneficiaries. 


\section{Quantity of food grains}

The beneficiaries under NFSA should get the full quota of food grains as per their eligibility. The result obtained was satisfactory with this standard both in rural and urban area. It is a matter of satisfaction that, all most all the beneficiaries of the sample area were getting full quota of ration under NFSA.

Many rural development programmes failed to deliver the tangible good and services to the beneficiaries in this country. However regarding the quantity of the food grain it was praiseworthy that the sample beneficiaries could get the full quota of food grain under the Public Distribution System. Almost all the beneficiaries of the rural $(100 \%)$ as well as the urban $(98.67 \%)$ sample area were getting full quota of the food grains as per their own opinion. Therefore it may be concluded that the NFS Act was successful with respect to supply of quantity of the food grains to the beneficiaries. A non- significant $\mathrm{CR}$ value denoted that there was no significant difference of opinion of the rural and urban sample respondents as far as the quantity of food grains were concerned.

\section{Opening of ration shops}

The ration shops are the nodal delivery centres of the food materials for the poor people of the country. As per the norm the FPS should open in all the working days in a month. The beneficiaries of the rural areas were so busy with their age old occupation and fragile livelihood that they sometimes miss the opportunity of lifting the ration in time. Moreover it is the practice in some locality of the country that the FPS is not opening sufficiently for the delivery of the commodities. Hence, the opinion of the respondents is reflected in the following lines.

The time of opening of the Fair price Shops and the opening hours for the beneficiaries were crucial and critical factors for the evaluation of the programme. The beneficiaries often found it difficult to access the shops as there was no fixed periodicity on the matter. It was noticed that, the rural respondents were almost satisfied about the issue and majority (92.67\%) of the rural beneficiaries had no complain about the opening of the ration shops.

Table.1 Timely availability of commodities under NFSA

\begin{tabular}{|l|l|l|l|l|l|l|l|l|}
\hline $\begin{array}{l}\text { Sl. } \\
\text { No. }\end{array}$ & Category & \multicolumn{3}{|l|}{ Rural(n1=150) } & \multicolumn{3}{l|}{ Urban(n2=150) } & \multicolumn{2}{l|}{ Pooled(n=300) } & $\begin{array}{l}\text { C. R } \\
\text { value }\end{array}$ \\
\hline & & f & $\%$ & f & $\%$ & f & $\%$ & \\
\hline $\mathbf{1}$ & YES & 145 & 96.67 & 140 & 93.33 & 285 & 95 & $0.98 \mathrm{NS}$ \\
\hline $\mathbf{2}$ & NO & 5 & 3.33 & 10 & 6.67 & 15 & 5 & \\
\hline
\end{tabular}

Table.2 Regularity of ration under NFSA

\begin{tabular}{|c|c|c|c|c|c|c|c|c|}
\hline \multirow{2}{*}{$\begin{array}{l}\text { Sl. } \\
\text { No. }\end{array}$} & \multirow[t]{2}{*}{ Category } & \multicolumn{2}{|c|}{$\operatorname{Rural}(n 1=150)$} & \multicolumn{2}{|c|}{$\operatorname{Urban}(\mathrm{n} 2=150)$} & \multicolumn{2}{|c|}{$\operatorname{Pooled}(n=300)$} & \multirow{2}{*}{$\begin{array}{l}\text { C. } R \\
\text { value }\end{array}$} \\
\hline & & f & $\%$ & $\mathrm{f}$ & $\%$ & $\mathrm{f}$ & $\%$ & \\
\hline 1 & YES & 141 & 94 & 139 & 92.67 & 280 & 93.33 & $0.98 \mathrm{NS}$ \\
\hline 2 & $\mathrm{NO}$ & 9 & 6 & 11 & 7.33 & 20 & 6.67 & \\
\hline
\end{tabular}


Table.3 Quality of food grains as per the FPS sample given to beneficiary

\begin{tabular}{|c|c|c|c|c|c|c|c|c|}
\hline \multirow{2}{*}{$\begin{array}{l}\text { Sl. } \\
\text { No. }\end{array}$} & \multirow[t]{2}{*}{ Category } & \multicolumn{2}{|c|}{ Rural(n1=150) } & \multicolumn{2}{|c|}{$\operatorname{Urban}(n 2=150)$} & \multicolumn{2}{|c|}{ Pooled(n=300) } & \multirow{2}{*}{$\begin{array}{l}\text { C. } \\
\text { value }\end{array}$} \\
\hline & & $\mathrm{f}$ & $\%$ & $\mathrm{f}$ & $\%$ & $\mathrm{f}$ & $\%$ & \\
\hline 1 & Yes & 139 & 92.67 & 92 & 61.33 & 231 & 77 & $9.15 * *$ \\
\hline 2 & Undecided & 11 & 7.33 & 9 & 6 & 20 & 6.67 & \\
\hline 3 & No & 0 & 0 & 49 & 32.67 & 49 & 16.33 & \\
\hline
\end{tabular}

Table.4 Quantity of food grains obtained by the beneficiaries

\begin{tabular}{|c|c|c|c|c|c|c|c|c|}
\hline \multirow{2}{*}{$\begin{array}{l}\text { Sl. } \\
\text { No. }\end{array}$} & \multirow[t]{2}{*}{ Category } & \multicolumn{2}{|c|}{ Rural(n1=150) } & \multicolumn{2}{|c|}{$\operatorname{Urban}(n 2=150)$} & \multicolumn{2}{|c|}{ Pooled(n=300) } & \multirow{2}{*}{$\begin{array}{l}\text { C. } \\
\text { value }\end{array}$} \\
\hline & & f & $\%$ & $\mathrm{f}$ & $\%$ & $\mathrm{f}$ & $\%$ & \\
\hline 1 & Full quota & 150 & 100 & 148 & 98.67 & 298 & 99.33 & $0.59 \mathrm{NS}$ \\
\hline 2 & No full quota & 0 & 0 & 2 & 1.33 & 2 & 0.67 & \\
\hline
\end{tabular}

Table.5 Satisfaction about the opening of ration shop

\begin{tabular}{|l|l|l|l|l|l|l|l|l|}
\hline $\begin{array}{l}\text { Sl. } \\
\text { No. }\end{array}$ & Category & \multicolumn{2}{|l|}{ Rural(n1=150) } & \multicolumn{2}{l|}{ Urban(n2=150) } & \multicolumn{2}{l|}{ Pooled(n=300) } & $\begin{array}{l}\text { C. } \\
\text { value }\end{array}$ \\
\hline & & f & $\%$ & f & $\%$ & f & $\%$ & \\
\hline $\mathbf{1}$ & Satisfied & 139 & 92.67 & 112 & 74.67 & 251 & 83.67 & $5.31^{* *}$ \\
\hline $\mathbf{2}$ & Undecided & 3 & 2 & 8 & 5.33 & 11 & 3.67 & \\
\hline $\mathbf{3}$ & Not satisfied & 8 & 5.33 & 30 & 20 & 38 & 12.66 & \\
\hline
\end{tabular}

However, $74.67 \%$ of the urban beneficiaries had satisfied about the issue and only $20 \%$ of them had complained that, the timing of the opening was not fixed and they missed the ration due to this reason sometimes. The reason being the diversified occupation of the dealers and they were busy in some other occupation by closing the FPS sometimes. As far as the pooled data was concerned it was observed that, a small proportion of $12.66 \%$ of the beneficiaries under NFSA were not satisfied with the opening timing, span of opening and regularity of opening of the ration shop.

A significant $C R$ value denoted that, there was difference in the opinion of the rural and urban beneficiaries on the satisfaction level of the opening of ration shops. It was observed that, few of the urban beneficiaries were more suffering for the closing of their ration shops.
Therefore it was suggested that, the dealers of urban areas should keep the ration shops open regularly for the necessary lifting of food grains by the beneficiaries. Moreover some of the respondents had suggested that, the distribution of the ration should be done by the Self Help groups (SHG) of the locality for ease of availability of the commodities.

In conclusion, public Distribution System (PDS) is a poverty alleviation programme and contributes towards the social welfare of the people. Essential commodities like rice, wheat, sugar, kerosene and the like are supplied to the people under the PDS at reasonable prices. PDS is a boon to the people living below the poverty line. PDS is the primary social welfare and antipoverty programme of the Government of India.

The result revealed that, almost all of the 
(95\%) beneficiaries had opined that, they were getting the ration in time except in some occasions. A total of $96.67 \%$ of the rural and $93.33 \%$ of the urban respondents had this opinion on the timely availability of the ration by the FPS. A total of $94 \%$ of the rural and $92.67 \%$ of the urban respondents had this opinion on the regular availability of the ration by the FPS. It is required that as per the NFSA norms the food grain provided to the beneficiaries should be at par with the sample put in their respective FPS. The data revealed that though $92.67 \%$ of the beneficiaries of the rural areas revealed that the quality was the same but $61.33 \%$ of the urban beneficiaries felt the same. It was a matter of some concern that $36.67 \%$ of the urban beneficiaries under NFSA felt that the quality of the food grains was not same as the sample given. Almost all the beneficiaries of the rural $(100 \%)$ as well as the urban $(98.67 \%)$ sample area were getting full quota of the food grains as per their own opinion. It was noticed that, the rural respondents were almost satisfied about the issue and majority $(92.67 \%)$ of the rural beneficiaries had no complain about the opening of the ration shops. However, 74.67 $\%$ of the urban beneficiaries had satisfied about the issue and only $20 \%$ of them had complained that, the timing of the opening was not fixed and they missed the ration due to this reason sometimes.

\section{References}

Aggarwal, P.K. (2008), Implications of global climate change for Indian agriculture, ISPRS Archives XXXVIII-8/W3 Workshop Proceedings: Impact of Climate Change on Agriculture, available at: www.isprs.org/proceedings/XXXVIII/8W3/FORMATTED\%20ISRO \% 20ABSTRACT.pdf (accessed October 15, 2014).

Amarasinghe, U.A., Shah, T. and Anand, B.K. (2007), India's water supply and demand from 2025-2050: business- as- usual scenario and issues, available at: http://publications.iwmi.

org/pdf/H041798.pdf (accessed May 15, 2014).

Chand, R. 2003. Government Intervention in Foodgrain Markets in the New Context. Policy Paper 19. New Delhi: National Centre for Agricultural Economics and Policy Research.

Deaton, A., and Drèze, J. (2009). Food and nutrition in India: Facts and interpretations. Economic and Political Weekly, 44(7), 4265.

Dev, S. M and A. N. Sharma. (2010): Food Security in India: Performance, Challenges and Policies", Oxfam India working papers series, OIWPS- VII.

FAO (Food and Agriculture Organization of the United Nations). 2014. FAO Rice Market $\begin{array}{llll}\text { Monitor } & 17 & \text { (3). } & \text { Rome. }\end{array}$ http://www.fao.org/3/a-i4147e.pdf. 2015. FAO Rice Market Monitor 18 (4). Rome. www.fao.org/fileadmin/templates/est/COM M_ MARKETS0_MONITORING/ Rice/Images/RMM/RMM_DEC15_H.pdf. Government of India (2014): "National Food Security Mission", http://nfsm.gov.in/

\section{How to cite this article:}

Kedarnath Mallick and Mohapatra, B.P. 2020. Evaluation of the National Food Security Act (NFSA) Programme in Odisha. Int.J.Curr.Microbiol.App.Sci. 9(07): 1965-1970. doi: https://doi.org/10.20546/ijcmas.2020.907.224 